\title{
Perencanaan Ulang Jembatan Lemah Ireng II pada Jalan Tol Semarang-Bawen Menggunakan Jembatan Busur Rangka Baja
}

\author{
Prasetyo Nur Hakikie dan Endah Wahyuni \\ Departemen Teknik Sipil, Fakultas Teknik Sipil dan Perencanaan, Institut Teknologi Sepuluh Nopember (ITS) \\ e-mail: endah@ce.its.ac.id
}

\begin{abstract}
Abstrak-Jembatan Lemah Ireng II terletak pada STA 21+912 STA 22+410 jalan tol Semarang-Bawen. Jenis jembatan Multi Span Continuous I-Girder dengan panjang bentang 298,15 dan lebar $2 \times 12 \mathrm{~m}$. Pada struktur bawah jembatan terdapat enam pilar dan dua abutmen. Perencanaan ulang dilakukan dengan menggunakan jembatan busur rangka baja menerus dengan lebar $12 \mathrm{~m}$ dan tinggi busur $20 \mathrm{~m}$. Desain jembatan busur menerus terbagi menjadi dua bagian yaitu, bentang tengah $100 \mathrm{~m}$ dan dua bentang tepi $50 \mathrm{~m}$.Perencanaan bangunan atas jembatan Lemah Ireng II menghitung antara lain, struktur lantai kendaraan, struktur baja ikatan angin, struktur baja rangka utama, struktur sambungan, dan desain perletakan. Dalam perencanaan ini harus memenuhi peraturan terbaru, antara lain SNI 1725:2016, RRSNI T-03-2005, SNI 2833:2008, SNI 2847:2013 serta peraturan lain yang berkaitan dengan perencanaan jembatan baja. Perencanaan rangka utama menggunakan kombinasi KUAT 1 (SNI 1725:2016), sedangkan perencanaan ikatan angin menggunakan kombinasi KUAT 3 (SNI 1725:2016). Perencanaan bangunan bawahpada tugas akhir ini menghitung struktur abutment, struktur pilar, dan pondasi bored pile. Abutment dan pilar menggunakan struktur beton bertulang sesuai dengan SNI 2847:2013. Hasil dari analisa struktur diperoleh: tebal pelat lantai kendaraan 20 cm, dimensi ikatan angin terbesar CHS 267,4x7, dimensi struktur rangka utama terbesar BOX 600x600x25, dimensi struktur rangka diagonal terbesar BOX 400x400x25, dimensi portal akhir BOX 600x600x25, diameter kabel penggantung 45 mm, perletakan menggunaan tipe POT bearing. Pondasi yang digunakan berupa pondasi bored pile dengan jumlah tiang pada abutment sebanyak 21 buah dan jumlah tiang pada pilar sebanyak 60 buah.
\end{abstract}

Kata Kunci-Lemah Ireng, jembatan busur rangka baja, jembatan busur menerus, POT bearing, bored pile.

\section{PENDAHULUAN}

$\mathrm{T}$ RANSPORTASI adalah pemindahan manusia atau barang dari satu tempat ke tempat lainnya dengan menggunakan sebuah kendaraan yang digerakkan oleh manusia atau mesin [1]. Menurut data Badan Pusat Statistik (2016) pada tahun 2014 jumlah kendaraan bermotor telah mencapai lebih dari seratus sepuluh juta kendaraan. Hal ini harus diimbangi dengan infrastruktur transportasi darat yang memadai dari segi kelayakan dan jumlahnya. Infrastruktur dalam hal ini dapat berupa jalan, jembatan, rambu lalu lintas, dan lain-lain.

Jalan tol merupakan salah satu infrastruktur yang ditargetkan akan dibangun sepanjang 1.000 kilometer dan selesei sebelum tahun 2019 [2]. Tujuan dari jalan tol adalah untuk mempersingkat jarak dan waktu tempuh kendaraan. Hal ini membuat jalan tol harus dibangun melintasi rintangan seperti sungai, jalan, perlintasan kereta api, dan lain-lain. Untuk menghindari rintangan tersebut dibutuhkan suatu sistem simpangan berupa jembatan atau terowongan.

Jembatan memiliki variasi bentuk desain, material, dan fungsi yang bermacam-macam. Sapanjang jalan tol seringkali terdapat lebih dari satu jembatan yang dibangun. Salah satu jembatan yang terdapat pada jalan tol adalah Jembatan Lemah Ireng II, terletak pada Jalan Tol SemarangBawen STA 21+912 sampai STA 22+410.Jembatan Lemah Ireng II menggunakan tipe Multi Span Countinuous I-Girder dengan panjang bentang $298,15 \mathrm{~m}$. Jembatan ini menopang jalan 4 lajur 2 arah dengan lebar $2 \times 12 \mathrm{~m}$. Struktur bawah menggunakan 6 buah kolom pier dan 2 buah abutment dengan jarak antar kolom pierantara $41 \mathrm{~m}-44 \mathrm{~m}$. Kolom pier memiliki tinggi $8 \mathrm{~m}-33 \mathrm{~m}$ dengan kedalaman bor pile antara $31 \mathrm{~m}-35 \mathrm{~m}$.

Struktur bawah Jembatan Lemah Ireng II memiliki banyak komponen dengan dimensi yang masif. Hal ini menjadi pertimbangan utama dalam memunculkan desain baru Jembatan Lemah Ireng II menggunakan Busur Rangka Baja. Adapun pemberian bentuk busur itu sendiri dimaksudkan untuk mengurangi momen pada jembatan sehingga penggunaan bahan menjadi lebih efisien dibandingkan gelagar parallel.

Pada perencanaannya, jembatan ini terdiri dari 2 bentang jembatan yang terletak berjajar dengan lebar masing-masing $12 \mathrm{~m}$. Pada middle span dengan panjang bentang $200 \mathrm{~m}$ digunakan Jembatan Busur Rangka Baja. Untuk side span dengan panjang bentang masing-masing $50 \mathrm{~m}$ digunakan Jembatan Rangka Baja yang dibangun menerus menyatu dengan middle span. Desain ini memiliki 3 buah kolom pier dan 1 buah abutment.

Dengan dibuatnya desain baru pada konstruksi Jembatan Lemah Ireng II ini diharapkan mampu menjadi solusi dalam merancang sebuah jembatan yang kuat secara struktural. Pemilihan sistem busur ini bertujuan agar kebutuhan material menjadi lebih efisien. Desain Jembatan Lemah Ireng II diharapkan mampu memberikan nilai lebih dalam segi estetika dan kesan monumental.

\section{METODOLOGI}

\section{A. Pengumpulan Data dan Studi literatur}

Pengumpulan data yang dilakukan meliputi peninjauan elevasi dan stationing dari jembatan eksisting, serta peninjauan kekuatan tanah di lokasi jembatan eksisting. Data umum yang perencanaan jembatan baru, antara lain :
- Lokasi
: STA 21+912 STA 22+410 Jalan Tol
Semarang-Bawen
- Jenis : Continuous Steel Arch Bridge
- Bentang : $200 \mathrm{~m}(50 \mathrm{~m}+100 \mathrm{~m}+50 \mathrm{~m})$
- Lebar $\quad: 12 \mathrm{~m}$ 


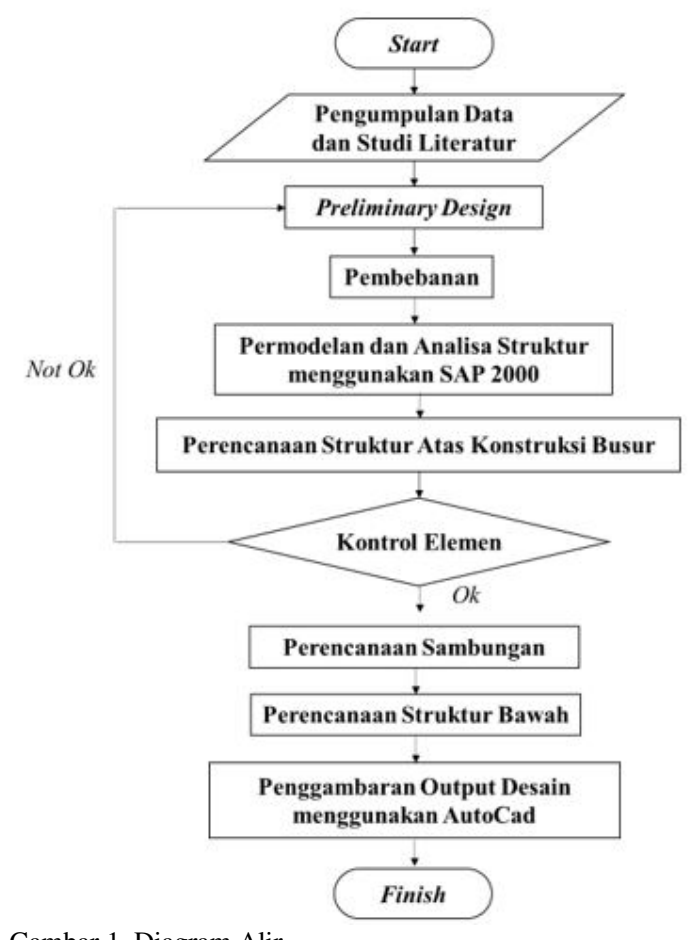

Gambar 1. Diagram Alir.

- Tinggi : $20 \mathrm{~m}$

- Material : Baja

Melakukan studi literatur dengan berpedoman beberapa standar peraturan sebagai bahan pustaka dalam pengerjaan tugas akhir, antara lain :

a. Bridges Management System (BMS) 1992

b. SNI 1725:2016

c. SNI 2847:2013

d. RSNI T-03-2005

e. SNI 2833:2008

B. Preliminary Design

1. Penentuan mutu bahan yang digunakan:

- Mutu Beton Pelat (f'c) $=40 \mathrm{MPa}$.

- Mutu Beton Pilar (f'c) $=40 \mathrm{MPa}$.

- Mutu Beton Abutment (f'c) = $40 \mathrm{MPa}$.

- Mutu Baja Tulangan (fy) = 390 dan $410 \mathrm{MPa}$

- $\quad$ Struktur utama (fy)

Profil Box BJ55 [3]

Profil Circullar Hollow BJ55 [4]

Profil WF [5] dan Siku BJ41 [4]

- Mutu baut sambungan menggunakan ASTM A325 untuk sambungan baut antar profil; [6]

- Mutu las yang digunakan adalah E70xx. [6]

2. Memperkirakan tebal pelat lantai kendaraan Pelat lantai yang berfungsi sebagai jalan kendaraan pada jembatan harus mempunyai tebal minimum $t s$, dengan ketebalan $20 \mathrm{~cm} \mathrm{[7].}$

Menentukan Dimensi Busur

- Tinggi Busur

$$
\text { Syarat : } \frac{1}{6} \leq \frac{f}{L}
$$

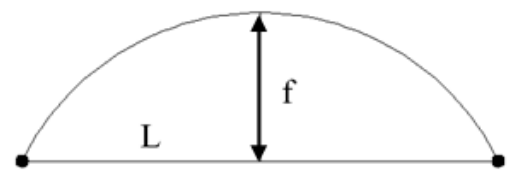

Gambar 2. Tinggi Busur.
- $\quad$ Tinggi Tampang Busur

Tinggi tampang busur rangka batang dengan batang tarik dapat menggunakan syarat sebagai berikut:

Syarat : $\frac{1}{40} \leq \frac{t}{L} \leq \frac{1}{20}$

- Lebar Jembatan

Lebar jembatan dapat menggunakan syarat sebagai berikut :

Syarat : $\frac{b}{L} \geq \frac{1}{20}$

3. Pembebanan [8]

Pembebanan yang bekerja pada struktur jembatan terdiri dari beban mati (berat sendiri dan beban mati tambahan), beban hidup, beban angin dan beban gempa.

C. Permodelan dan Analisa Struktur Utama dengan Program SAP2000

Tugas Akhir ini memodelkan Jembatan Lemah Ireng II dengan menggunakan progam bantu SAP2000. Pemodelan 2 Dimensi untuk mendapatkan garis pengaruh pada jembatan dan pemodelan 3 Dimensi untuk mendapatkan profil yang digunakan sesuai kombinasi pembebanan SNI 1725-2016 $[8]$.

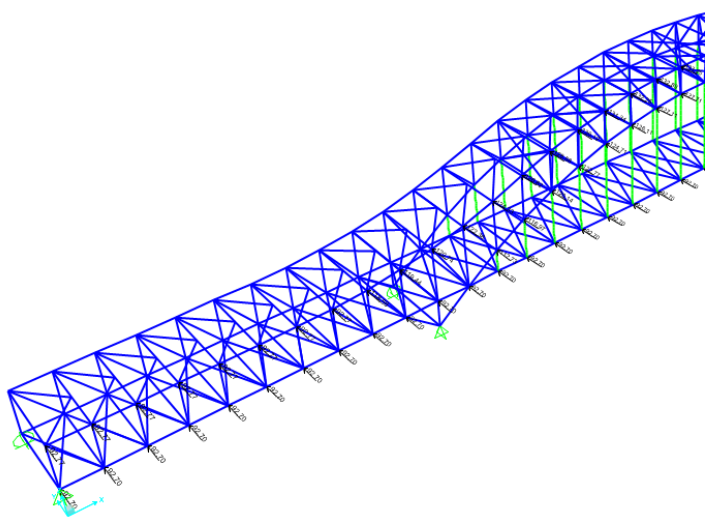

Gambar 3. Pemodelan Jembatan 3D dengan SAP2000.

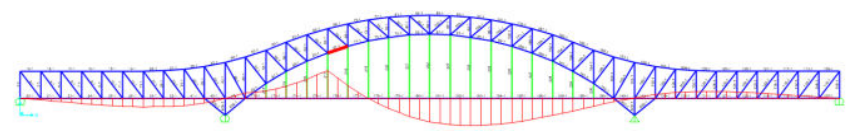

Gambar 4. Pemodelan Jembatan 2D dengan SAP2000 untuk Mencari Garis Pengaruh.

\section{Perencanaan Struktur Atas}

Pelat lantai kendaraan direncanakan dengan panjang $5 \mathrm{~m}$ dan lebar 1,5 m menggunakan beton bertulang. Tebal beton bertulang $20 \mathrm{~cm}$ dengan lapisan perkerasan aspal setebal 6 $\mathrm{cm}$. Pelat lantai kendaraan menumpu langsung pada gelagar memanjang dan melintang yang didesain menggunakan material dari JFE Steel Coorporation [5] untuk profil WF dengan mutu baja ASTM A36 (fu $=410 \mathrm{Mpa}$ dan fy $=250$ Mpa). Profil untuk gelagar memanjang berupa WF 450x300x11x18 dan untuk gelagar melintang berupa WF $950 \times 425 \times 28,4 \times 51,1$.

Profil ikatan angin pada rangka busur ataupun pada lantai kendaraan menggunakan profil circular hollow sesuai dengan Buku Tabel Profil Baja [4]. Profil yang digunakan antara lain:

Ikatan Angin Atas : Circular Hollow 267,4 x 7

Ikatan Angin Silang : Circular Hollow 216,3 x 8 
Ikatan Angin Bawah: Circular Hollow 216,3 x 7

Profil rangka utama menggunakan produk dari PT. Gunung Garuda [3]. Bagian jembatan terditi dari tiga segmen untuk mempermudah dalam pemilihan profil. Profil yang digunakan setiap segmen antara lain:

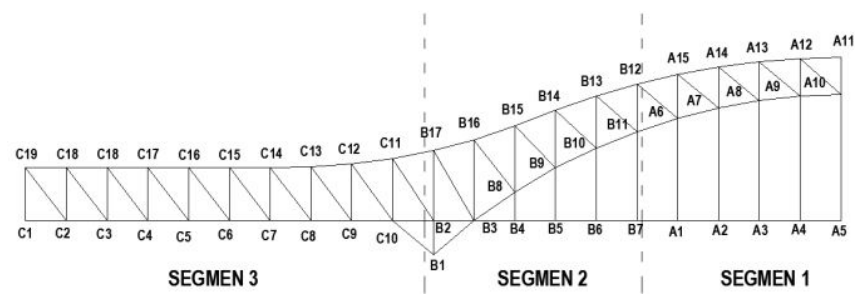

Gambar 5. Pembagian Segmen Jembatan.

Tabel 1.

Rekapitulasi Profil Rangka Utama

\begin{tabular}{|c|c|c|}
\hline \multirow{4}{*}{$\begin{array}{c}\text { SEGMEN } \\
1\end{array}$} & Busur Atas & BOX 600x600x25 \\
\hline & Busur Bawah & BOX 500x500x25 \\
\hline & Batang Diagonal & BOX 250x250x16 \\
\hline & Batang Tarik & BOX 500x $500 \times 25$ \\
\hline \multirow{4}{*}{$\begin{array}{c}\text { SEGMEN } \\
2\end{array}$} & Busur Atas & BOX 500×500×25 \\
\hline & Busur Bawah & BOX $600 \times 600 \times 25$ \\
\hline & Batang Diagonal & BOX $350 \times 350 \times 16$ \\
\hline & Batang Tarik & BOX 500x500x25 \\
\hline \multirow{4}{*}{$\begin{array}{c}\text { SEGMEN } \\
3\end{array}$} & Rangka Atas & BOX 500×500×25 \\
\hline & Rangka Bawah & BOX 500x500x25 \\
\hline & Batang Diagonal & BOX 350x350x16 \\
\hline & Batang 40,39,44,43,46.48 & BOX 400x400x25 \\
\hline
\end{tabular}

Perencanaan kabel penggantung menggunakan kabel dan fitting dari perusahaan PFEIFER-Zugglieder [9] tipe PV-195 dengan diameter strand $45 \mathrm{~mm}$ dan breaking load sebesar $1930 \mathrm{kN}$.

Perletakaan yang digunakan mengguanakan POT Bearing dari perusahaan VSL dengan tipe PL 560/400 (free), PU 3900/2800 (guided), PL 1700/1200 (free), PU 3100/2200 (guided), PF 3900/2800 (fixed).

\section{E. Kontrol Gaya Dalam}

1. Kontrol Kapasitas Tarik

Batas kekuatan [6]

$\mathrm{N}_{\mathrm{u}} \leq N_{n}$

Nilai $\mathrm{N}_{\mathrm{n}}$ diambil sebagai nilai terendah dari beberapa persamaan dibawah ini :

Kontrol leleh : $\mathrm{N}_{\mathrm{u}} \leq \emptyset_{t} f_{y} A_{g} \quad \emptyset_{t}=0.75$

Kontrol putus: $\mathrm{N}_{\mathrm{u}} \leq \emptyset_{t} f_{u} A_{e} \quad \emptyset_{t}=0.75$

Luas Penampang Efektif :

$\mathrm{A}_{\mathrm{e}}=\mathrm{A} \times\left(1-\frac{x}{L}\right)$

Dimana :

$\mathrm{N}_{\mathrm{u}}$ : Gaya Tarik aksial terfaktor $(\mathrm{N})$

$f_{y}$ : Tegangan leleh (MPa)

$f_{u}$ : Tegangan tarik putus (MPa)

$\mathrm{A}_{\mathrm{g}}$ : Luas penampang bruto $\left(\mathrm{mm}^{2}\right)$

$A_{e}$ : Luas penampang efektif $\left(\mathrm{mm}^{2}\right)$

$\mathrm{x}$ : eksentrisitas sambungan $(\mathrm{mm})$

2. Kontrol Kapasitas Tekan

Batas kekuatan [6]

$N_{u} \leq \phi_{n} N_{n} \quad \phi_{n}=0.85$

Kekuatan tekan nominal

$N_{n}=\left(0.66^{\lambda_{c}{ }^{2}}\right)$ Agfy untuk $\lambda_{c} \leq 1,5$

$N_{n}=\frac{(0,88)}{\lambda_{c}{ }^{2}} A g f y \quad$ untuk $\lambda_{c} \geq 1,5$

$\lambda_{c}=\frac{L_{k}}{r \pi} \sqrt{\frac{f y}{E}}$

$\mathrm{Lk}=\mathrm{K}_{\mathrm{cx}} \mathrm{L}$

Dimana :
$\mathrm{N}_{\mathrm{n}}$ : Kuat tekan nominal komponen (N)

$\mathrm{K}_{\mathrm{c}}$ : Faktor panjang tekuk untuk komponen struktur $\lambda_{c}$ : Kelangsingan Komponen Struktur Tekan

\section{F. Perhitungan Sambungan}

Sambungan yang digunakan pada Tugas Akhir ini adalah sambungan baut tipe friksi dan sambungan las

- Kuat geser nominal [6] :

$(\mathrm{Vn})=1.13 \times \mu \times \mathrm{m} \times \mathrm{Tb} \times \pi$

Kuat rencana :

$\mathrm{V}_{\mathrm{d}}=\emptyset \mathrm{Vn}$

Dimana :

- $\quad \mu \quad$ : Koefisien geser (permukaan bersih $=0,35$ )

- $m$ : jumlah bidang geser

- $\mathrm{Tb}$ : gaya Tarik minimum baut

- $\varnothing: 0.75$

- $\pi \quad: 1,00$ untuk lubang standar

Tabel 2.

Gaya Tarik Baut Minimum

\begin{tabular}{cc}
\hline \hline Diameter nominal baut $(\mathrm{mm})$ & $\begin{array}{c}\text { Gaya tarik minimum } \\
(\mathrm{kN})\end{array}$ \\
\hline 16 & 95 \\
20 & 145 \\
24 & 210 \\
30 & 335 \\
36 & 490 \\
\hline \hline
\end{tabular}

Jumlah Baut (n) :

$\frac{V u}{V_{d}}$

Jarak antar Baut :

Syarat : $2.5 \mathrm{~d}_{\mathrm{b}} \leq \mathrm{S} \leq 15 \mathrm{t}_{\mathrm{p}}$

Jarak Baut ke Tepi :

Syarat : $1.5 \mathrm{~d}_{\mathrm{b}} \leq \mathrm{S} 1 \leq\left(4 \mathrm{t}_{\mathrm{p}}+100\right)$

Kontrol Las :

$1 \mathrm{~cm}$ las $: R u=\emptyset \cdot$ te $\cdot 0,6 \cdot F E 70 x x$

Panjang las minimum $=\frac{P u}{R u}$

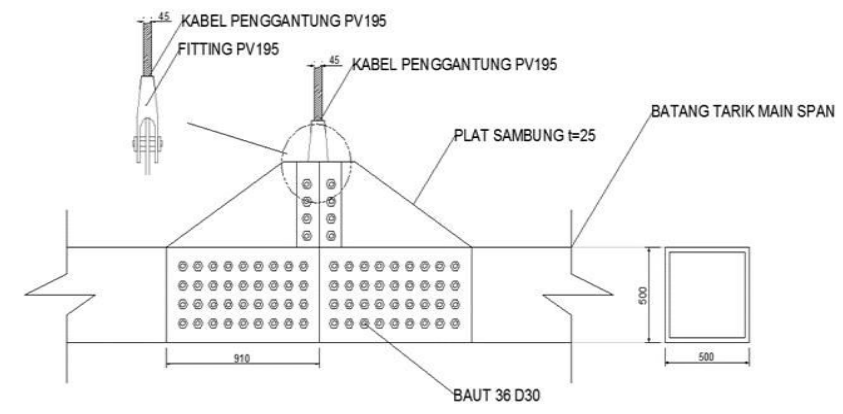

Gambar 6. Sambungan titik simpul A5.

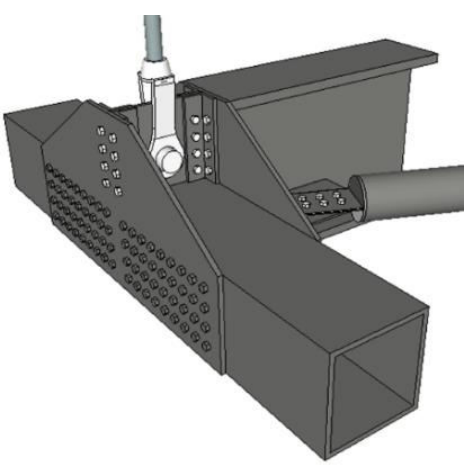


Gambar 7. Sambungan titik simpul A5 (perspektif).

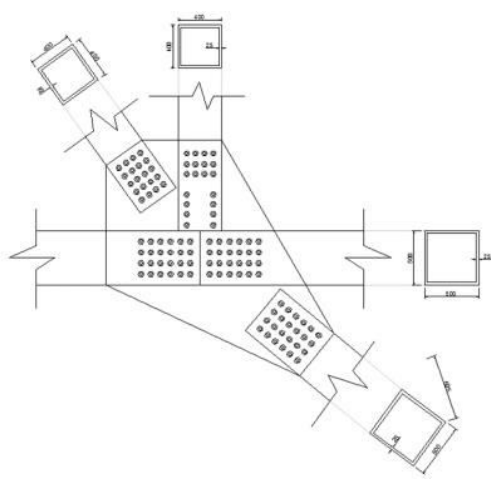

Gambar 8. Sambungan titik simpul C10.

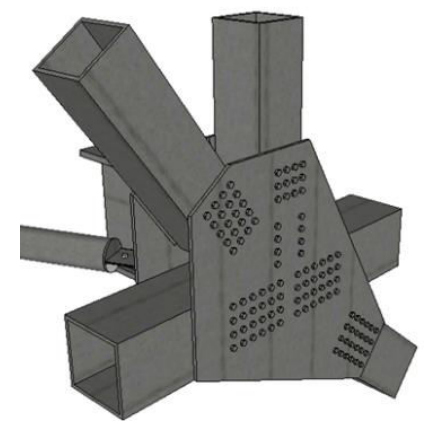

Gambar 9. Sambungan titik simpul C10 (perspektif).

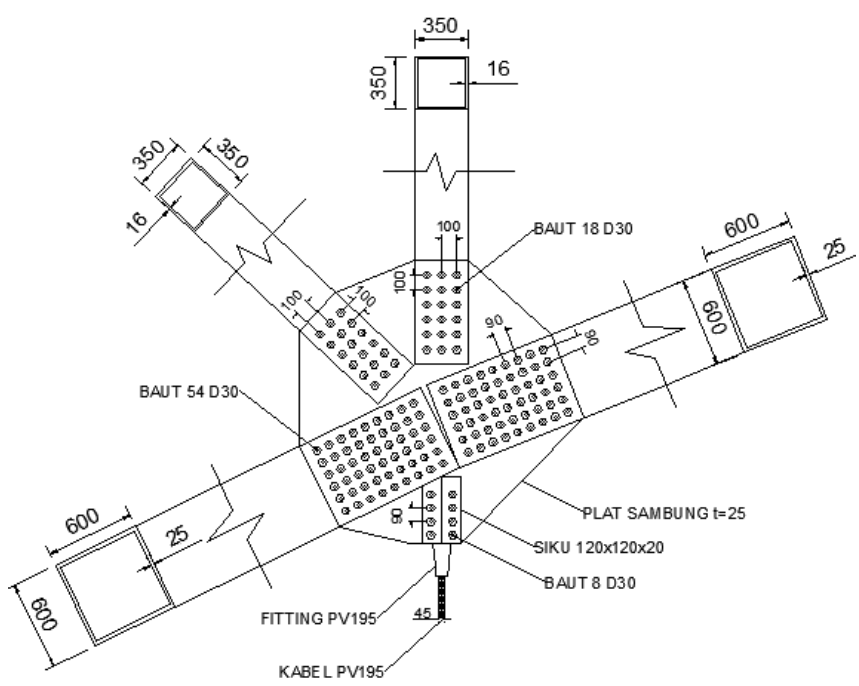

Gambar 10. Sambungan titik simpul B10.

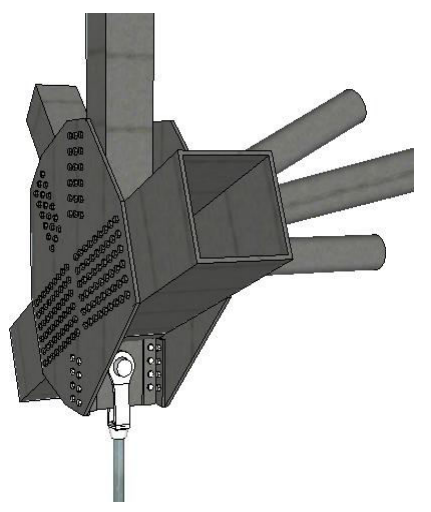

Gambar 11. Sambungan titik simpul B10 (perspektif).

\section{G. Perencanaan Abutment}

Direncanakan bored pile dengan diameter 1,2 m dengan kedalaman $20 \mathrm{~m}$. Dengan $\mathrm{SF}=3$ maka didapatkan $\mathrm{P}_{\mathrm{ijin}} 1$ Tiang $=394,11$ ton. Daya dukung tiang harus dikoreksi sesuai dengan persamaan Converse-Labare [10]:

$C_{e}=1-\frac{\arctan \left(\frac{S_{1}}{S}\right)}{90} x\left(2-\frac{1}{m}-\frac{1}{n}\right)$

Dengan faktor koreksi sebesar 0,67 maka didapatkan $\mathrm{P}_{\mathrm{ijin}}$ grrup $=266,34$ ton.

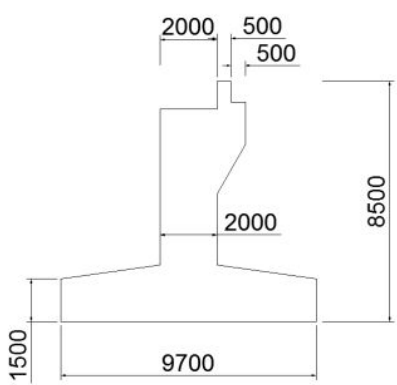

Gambar 12. Desain Abutment

Pembebanan pada abutment sesuai dengan SNI 17252016 [6]. Berikut hasil kombinasi dan konfigurasi tiang yang dipakai,

Tabel 3.

Gaya Luar Abutment

\begin{tabular}{|l|c|c|c|c|c|c|}
\hline \multirow{2}{*}{ Beban } & \multicolumn{2}{|c|}{ Gaya Tak Terfaktor (ton) } & \multirow{2}{*}{ Lengan (m) } & \multicolumn{2}{c|}{ Momen (tonm) } \\
\cline { 2 - 6 } & $\mathrm{V}$ & $\mathrm{Hy}$ & $\mathrm{Hx}$ & & $\mathrm{My}$ & $\mathrm{Mx}$ \\
\hline KUAT 1 & 2104,23 & & $-267,568$ & & $-113,551$ & 555,7246 \\
\hline KUAT 3 & 1720,036 & & $-287,818$ & & 810,2244 & 526,9746 \\
\hline EKSTREM 1 & 1784,068 & $-873,936$ & 37,28708 & & $-4764,42$ & 1473,237 \\
\hline
\end{tabular}

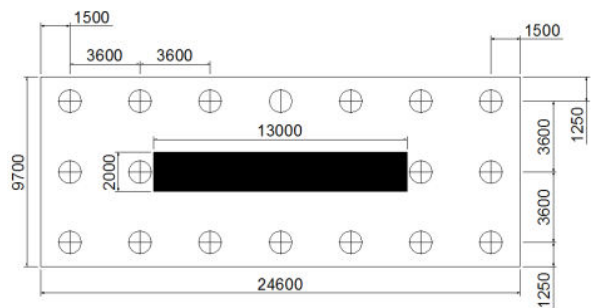

Gambar 13. Konfigurasi Tiang Abutment.

$P v=\frac{\sum P}{n}+\frac{M x \cdot y \max }{\sum y^{2}}+\frac{M y \cdot x \max }{\sum x^{2}}[10]$

$P v=209,349$ ton $<P$ ijin grup $=266,34$ ton

$O K$

Perencanaan penulangan utama menggunakan program bantu SpColumn dan didapatkan tulangan abutment 546D30 dengan rasio $1,6 \%$.

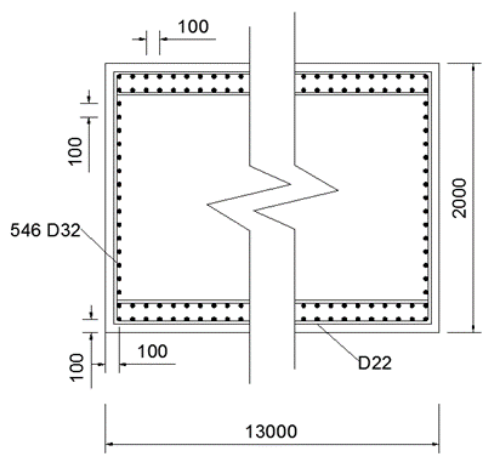


Gambar 14. Ilustrasi Tulangan Utama Abutment.

\section{H. Perencanaan Pilar}

Direncanakan bored pile dengan diameter 1,2 $\mathrm{m}$ dengan kedalaman $35 \mathrm{~m}$. Dengan $\mathrm{SF}=3$ maka didapatkan $\mathrm{P}_{\mathrm{ijin}} 1$ Tiang $=721,14$ ton. Daya dukung tiang harus dikoreksi sesuai dengan persamaan Converse-Labare [10] :

$C_{e}=1-\frac{\arctan \left(\frac{S_{1}}{S}\right)}{90} \times\left(2-\frac{1}{m}-\frac{1}{n}\right)$

Dengan faktor koreksi sebesar 0,63 maka didapatkan $\mathrm{P}_{\mathrm{ijin}}$ grrup $=455,203$ ton.

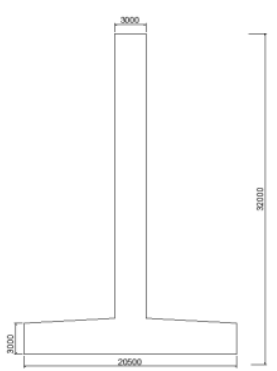

Gambar 15. Desain Pilar.

Pembebanan pada pilar sesuai dengan SNI 1725-2016 [6]. Berikut hasil kombinasi dan konfigurasi tiang yang dipakai,

Tabel 4.

Gaya Luar Pilar

\begin{tabular}{|l|c|c|c|c|c|c|}
\hline \multirow{2}{*}{ Beban } & \multicolumn{3}{|c|}{ Gaya Tak Terfaktor (ton) } & \multirow{2}{*}{ Lengan (m) } & \multicolumn{2}{c|}{ Momen (tonm) } \\
\cline { 2 - 3 } & $\mathrm{V}$ & $\mathrm{Hy}$ & $\mathrm{Hx}$ & & $\mathrm{My}$ & $\mathrm{Mx}$ \\
\hline KUAT1 & 10342,44 & & 20,25 & & 175,4134 & 648 \\
\hline KUAT3 & 8990,207 & 58,33226 & & & 1411,06 & 0 \\
\hline EKSTREM 1 & 9215,58 & 2887,062 & 2293,334 & & 37444,35 & 36696,23 \\
\hline
\end{tabular}

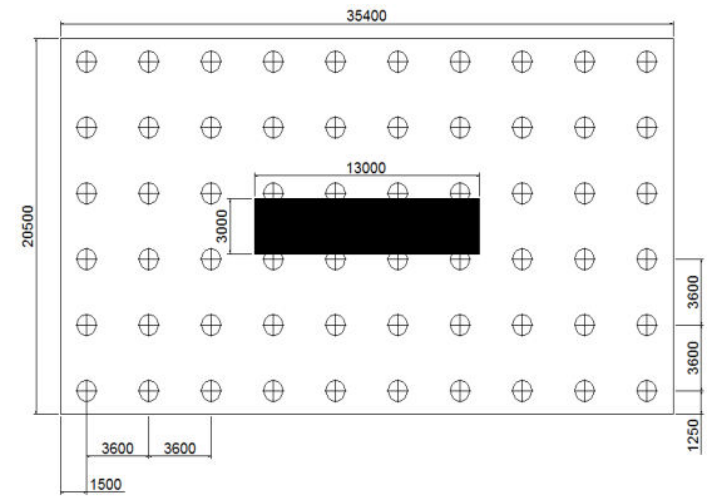

Gambar 16. Konfigurasi Tiang Pilar.

$P v=\frac{\sum P}{n}+\frac{M x \cdot y \max }{\sum y^{2}}+\frac{M y \cdot x \max }{\sum x^{2}}$

$P v=413,63$ ton $<P$ ijin grup $=455,203$ ton $O K$

Perencanaan penulangan utama menggunakan program bantu SpColumn dan didapatkan tulangan pilar 1080-D32 dengan rasio $2,23 \%$.

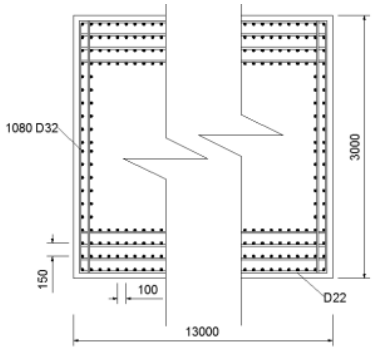

Gambar 17. Ilustrasi Tulangan Utama Pilar.

\section{KESIMPULAN}

1. Perencanaan pelat lantai kendaraan merupakan pelat beton $40 \mathrm{MPa}$ dengan ketebalan $20 \mathrm{~cm}$ dan dilapisi aspal dengan ketebalan $6 \mathrm{~cm}$.

2. Hasil perencanaan gelagar dan ikatan angin didapatkan :

Gelagar Memanjang: WF 450x300x11x18

Gelagar Melintang : WF 950x425x28,4x51,1

Ikatan Angin Atas : Circular Hollow 267,4 x 7

Ikatan Angin Silang : Circular Hollow 216,3 x 8

Ikatan Angin Bawah: Circular Hollow 216,3 x 7

3. Profil rangka utama menggunakan brosur PT. Gunung Garuda yang memiliki mutu BJ55 sesuai RSNI T-032005. Seluruh profil yang digunakan dalam rangka jembatan adalah profil BOX.

4. Kabel penggantung yang dipakai adalah kabel strand dari perusahaan PFEIFER-Zugglieder. Tipe kabel adalah PV 195 dengan diameter 45mm.

5. Perletakan yang digunakan adalah perletakan jenis POT bearing produk dari VSL.

6. Desain abutmen dengan tinggi $8,5 \mathrm{~m}$, lebar $13 \mathrm{~m}$, dan tebal $2 \mathrm{~m}$ dengan 21 tiang diameter $1,2 \mathrm{~m}$ sedalam 20 $\mathrm{m}$.

7. Desain pilar dengan tinggi $32 \mathrm{~m}$, lebar $13 \mathrm{~m}$, dan tebal $3 \mathrm{~m}$ dengan 60 tiang diameter $1,2 \mathrm{~m}$ sedalam $35 \mathrm{~m}$.

\section{DAFTAR PUSTAKA}

[1]

N. Rianty, "Pengertian Transportasi," 2015. [Online]. Available: http://www.sridianti.com/pengertian-transportasi.html.

[2] Infonawacita, "Skema dan Target Pembangunan Jalan Tol yang Dirancang Pemerintah," 2016. [Online]. Available: http://www.infonawacita.com/skema-dan-target-pembangunanjalan-tol-dirancang-pemerintah.

[3] PT. Gunung Garuda, "Angle (Hot Rolled)," Bekasi, 2016.

[4] R. Gunawan, Tabel Profil KONSTRUKSI BAJA. Yogyakarta: Kanisius, 1987.

[5] JFE Steel Corporation, "Wide Flange Shapes," Japan, 2011.

[6] Badan Standarisasi Nasional, "Standar Perencanaan Struktur Baja untuk Jembatan (RSNI T-03:2005),” Bandung, 2005.

[7] Badan Standardisasi Nasional, "Bridge Management System (BMS) Peraturan Perencanaan Teknik Jembatan," Jakarta, 1992.

[8] Badan Standarisasi Nasional, "Standar Pembebanan Untuk Jembatan (SNI 1725:2016)," Bandung, 2016.

[9] PFEIFER-Zugglieder, PFEIFER Seilbau Cable Structure. Memmingen: PFEIFER-Zugglieder, 2015.

[10] H. Wahyudi, Daya Dukung Pondasi Dalam. Surabaya: Jurusan Teknik Sipil FTSP - ITS, 1999. 